\section{Role of human papillomaviruses in esophageal carcinoma: an updated
systematic review from 1982 to 2013 esophageal carcinoma: an updated
systematic review from 1982 to 2013}

Mario Poljak*, ${ }^{*, 1}$ Boštjan J Kocjan \& Lea Hošnjak

\begin{abstract}
Tobacco, alcohol and betel quid are known etiological agents of esophageal squamous cell carcinoma (ESCC). A meta-analysis in 2012 and a literature update (1982-August 2013) identified 159 studies with a total of 11,310 ESCCs tested for the presence of human papillomaviruses (HPVs). HPV DNA was present in $30.3 \%$ of ESCCs, with substantial geographic differences. A recent meta-analysis of 21 case-control studies investigating the HPV-ESCC association showed that HPVs increase the risk of ESCC at least threefold. Vaccinepreventable HPV-16 and HPV-18 are the most commonly identified HPV types in ESCC in both low- and high-incidence settings. HPVs should now be seriously considered as etiological agents for at least a subset of ESCC, and more studies are needed to provide conclusive evidence that HPVs cause ESCC.
\end{abstract}

\section{Human papillomaviruses are the most important viral etiological agents of human cancers}

Human papillomaviruses (HPVs) are a large and diverse group of small, double-stranded circular DNA viruses that are etiologically linked with various benign and malignant lesions of the skin and mucosa. The HPV genome, typically $7-8 \mathrm{~kb}$ in size, is divided into three main regions. The early region contains proteins - typically E1, E2, E4, E5, E6 and E7 - involved in viral replication, transcription and transformation, and the late region encodes two capsid proteins, L1 and L2. The long control region is noncoding, and controls viral transcription and DNA replication [1].

HPVs are phylogenetically placed in the Papillomaviridae family, which is additionally divided into viral genera and species. On a lower taxonomic level, HPVs are further classified into types, subtypes and genomic variants. HPV type is defined as a viral genome whose L1 gene sequence is at least $10 \%$ different from any other officially recognized HPV type [2]. Although the definition of viral type was introduced somewhat arbitrarily, subsequent studies have confirmed that the distance criterion of $10 \%$ describes natural taxa that are also of clinical relevance [1].

At present, over $220 \mathrm{HPV}$ types have been described, of which 170 have been officially designated and taxonomically defined. Currently, HPV types are classified into five major genera, designated by the Greek letters $\alpha, \beta, \gamma, \mu$ and $v$, each consisting of one to 15 viral species [1]. HPV types from the genus Alphapapillomavirus ( $\alpha-\mathrm{PV}$ ) are predominantly found in anogenital (mucosal) sites, while types from Betapapillomavirus ( $\beta$-PV), Gammapapillomavirus ( $\gamma$-PV), Mupapillomavirus ( $\mu$-PV) and Nupapillomavirus ( $v$-PV) genera typically infect skin and hair follicles $[1,3]$. In addition, it was recently shown that $\beta$-PVs and phylogenetically related $\gamma$-PVs can also be detected at various mucosal sites of the head and neck region, esophagus and anal canal, indicating that these viruses may share a dual tissue tropism $[3,4]$.

IInstitute of Microbiology \& Immunology, Faculty of Medicine, University of Ljubljana, Slovenia

*Author for correspondence: University of Ljubljana, Faculty of Medicine, Institute of Microbiology \& Immunology, Zaloška 4,

1105 Ljubljana, Slovenia; Tel.: +386 1543 7415; Fax: +3861543 7418; mario.poljak@mf.uni-lj.si

\section{KEYWORDS}

- esophageal cancer

- esophageal carcinoma

- etiology • HPV • human

papillomaviruses 
The clinically most important genus, $\alpha-P V$, contains more than 40 different HPV types and derives from a grouping originally referred to as 'mucosal' or 'genital' HPVs. Twelve HPV types from the $\alpha-\mathrm{PV}$ genus are defined by WHO as group 1 human carcinogens [5]. These $12 \mathrm{HPV}$ types, the most important of which is HPV-16, are etiologically linked to virtually all cases of cervical carcinomas, $88 \%$ of anal carcinomas, $66-70 \%$ of vaginal carcinomas, $50 \%$ of penile carcinomas, $43 \%$ of vulvar carcinomas and $13-56 \%$ of oropharyngeal carcinomas (including tonsils and the base of the tongue; reviewed in [6]). Some HPV types from the $\alpha-P V$ genus, the most important being HPV-6 and HPV-11, are only exceptionally associated with human cancers but, on the other hand, are causally involved in the development of virtually all cases of anogenital warts and laryngeal squamous cell papillomas [7]. Genus $\alpha-P V$ additionally contains some HPV types, mainly from $\alpha$-PV species 2 and 4, which preferentially infect skin epithelia and cause benign skin lesions such as common warts [2].

Genus $\beta-P V$ comprises HPV types associated with the development of benign skin lesions and nonmelanoma skin cancer mainly in immunocompromised individuals and patients with the rare hereditary disease Epidermodysplasia verruciformis. In subjects who are not genetically predisposed, $\beta$-PVs establish latent, asymptomatic infections or induce (although rarely) benign cutaneous neoplastic lesions $[2,8,9]$. HPV types belonging to genera $\gamma$-PV, $\mu-P V$ and $\nu$-PV cause various skin lesions that do not generally progress to skin cancer $[2,8]$.

\section{Esophageal cancer shows remarkable regional variations in incidence rates}

In 2008, approximately 12.7 million new cancer cases and 7.6 million cancer deaths occurred worldwide, with esophageal cancer being the eighth most common cancer and the sixth most common cause of death from cancer [10]. The estimated number of new cases of esophageal cancer and deaths caused by this type of cancer were 481,000 (3.8\% of the total number of new cancer cases worldwide) and 406,000 (5.4\% of the total number of deaths caused by cancer worldwide), respectively [11].

In both genders, esophageal cancer is most prevalent in the older age group, with a median age of 65 years, and extremely rare in individuals younger than 30 years [12]. According to the most recent GLOBOCAN report, esophageal cancer mostly affects males in all parts of the world; 68\% $(326,000)$ of new esophageal cancer patients in 2008 were males. In low-income countries, males have a two-times greater lifetime risk of developing esophageal cancer than females, whereas the difference can be up to four-times in some high-income countries [10].

One of the most intriguing features of esophageal cancer is the remarkable regional variations in its incidence $[10,13]$. In most countries, the incidence rates are around $2.5-5.0$ per 100,000 for males and 1.5-2.5 per 100,000 for females [10]. However, in distinct areas, the incidence rates are considerably higher, varying up to 500 -fold from one country/area to another, and even between different ethnic groups within the same country/area [13]. Generally, the lifetime risk of acquiring esophageal cancer is more than 15-fold higher in men and almost 20-fold higher in women from high-risk areas (China, Iran and South Africa) in comparison to low-risk areas (Europe, North America and Western Africa) [11]. Additionally, in high-risk areas, the disease may occur up to 15 years earlier than in low-risk countries [13].

The so-called Asian esophageal cancer belt (the area that extends from northeastern China to the Caspian littoral of northern Iran) and the Transkei region of South Africa have been identified as areas with the world's highest incidence of esophageal cancer, with incidence rates as high as 246 per 100,000 [13,14]. Generally, China is the most affected country in the world, where esophageal cancer is the fourth most common cause of death from cancer, accounting for 11.8 and $9.2 \%$ of all cancer deaths among men and women, respectively. There were more than 250,000 new esophageal cancer cases recorded in China in 2008 and the estimated overall age-adjusted incidence rate standardized for the world population (ASR[W]) for both sexes was 16.7 per 100,000 [10]. The incidence rate of esophageal cancer varies greatly across China and is higher in rural (highest in Linxian in the Henan Province of northern China) in comparison to urban areas such as Beijing and Shanghai [13]. Similarly to China, the incidence rate of esophageal cancer in Iran is higher in some parts of the country, such as Turkmen Sahra, a region in the northeast of the country near the Caspian Sea, with an estimated annual incidence rate of 8.8 per 100,000 [15]. When the entire country is taken into consideration, Iranian $\operatorname{ASR}(\mathrm{W})$ is 
lower, at 6.8 per 100,000 [10]. In South Africa, annual deaths due to esophageal cancer account for $13.2 \%$ of all cancer-related deaths among men and $10.4 \%$ among women, with an incidence rate of 17.3 per 100,000 [10]. Generally, Europe is a low-risk area for the development of esophageal cancer, with the highest ASR(W)s reported from the UK (6.4 per 100,000), Ireland (5.9 per 100,000$)$ and The Netherlands $(5.8$ per 100,000) [10].

In terms of histological classification, esophageal cancer can be divided into several subtypes, of which esophageal squamous cell carcinoma (ESCC) and adenocarcinoma are the most common and represent $90 \%$ of all esophageal cancers. Even though the incidence rate of esophageal adenocarcinoma has increased in developed countries in recent years, ESCC remains the most frequently diagnosed esophageal cancer subtype in developing countries and still accounts for a major part of all esophageal cancer cases worldwide [16].

\section{Etiology of esophageal carcinoma is still unresolved}

Despite extensive research, the etiology of ESCC is still unresolved and is probably multifactorial, since it is hardly possible that a single etiological factor could account for such remarkable regional variations in the incidence rates of ESCC. Additionally, many researchers strongly believe that distinct risk-factors are responsible for the development of ESCC in high-risk and low-risk areas $[13,14]$.

In high-income countries, which are mostly considered to be low-risk areas for the occurrence of esophageal cancer, commonly accepted main risk-factors for the development of ESCC are excessive alcohol and tobacco consumption, especially when the two are combined $[16,17]$. One study thus showed that in relation to exposure to a single risk-factor, simultaneous exposure to moderate amounts of alcohol and tobacco increased the risk of ESCC 12-19-fold in men and women, respectively [18].

On the other hand, convincing epidemiological, clinical and experimental data suggest that in low-income countries (many also considered to be high-risk countries for ESCC), the inhabitants are frequently and continuously exposed to some chemical, physical and biological factors that may alone or more probably synergistically lead to the development of ESCC $[13,14,17]$. The most frequently attributed chemical agents are nitrosamines and their precursors (mainly derived from tobacco and/or the areca nut, the primary ingredient of betel quid), mycotoxins with tumorigenic properties (fumonisins B1 and B2), environmental pollutants, industrial chemicals (perchlorethylene), combustion products and asbestos, opium as well as tobacco smoke, smokeless tobacco and excessive alcohol intake $[13,16,17]$. Tobacco, betel quid with or without added tobacco, alcohol and acetaldehyde associated with alcoholic beverages have thus recently been officially classified by the WHO International Agency for Research on Cancer (IARC) as group 1 human carcinogens linked with esophageal carcinoma [17]. Among physical factors most frequently cited are those leading to physical or thermal (ingestion of coarse and hot food and hot liquids) injury of the esophageal mucosa and exposure to radiation [19]. A diet high in processed and red meat and low in fresh fruit and vegetables, generating nutritional deficiencies such as deficiency of vitamins A, B, $\mathrm{C}$ and trace elements (molybdenum and zinc), is also frequently cited as a possible risk-factor for ESCC development in low-income countries $[13,14]$. Finally, several biological agents, ranging from bacteria (producing carcinogenic chemicals and/or increasing cell proliferation while stimulating the inflammatory process), fungi (fungal toxins capable of nitrosamine production) and some viruses have been proposed as possible etiological agents of ESCC [20]. However, among biological agents, only evidence linking HPV to ESCC is increasing in strength with time, as discussed in detail below.

The first scientific reports suggesting an etiological role of HPV in the development of both benign and malignant neoplasms of the esophagus date back to 1982 [21]. These initial observations were based on the discovery of morphological similarities between HPV-associated lesions in the genital tract (genital warts) and squamous cell tumors of the esophageal mucosa (esophageal squamous cell papillomas and esophageal carcinomas). These morphological findings were subsequently confirmed by the demonstration of HPV structural proteins and parts of the viral genome in benign and malignant esophageal lesions, using immunohistochemistry (IHC) and various DNA hybridization and amplification techniques (reviewed in [22]). Additional serological and in vitro transformation studies, studies on animal models and demonstration of viral oncogene transcripts in tumorous lesions 
have confirmed that HPV may have a role in the development of ESCC (reviewed in [13]).

\section{HPV \& esophageal cancer: 30 years of confusing results}

In the last three decades, the literature reporting the detection of different HPV types in ESCC from different geographical regions has expanded rapidly, resulting in more than 150 peer-reviewed publications, varying from case reports to case-control studies [20]. However, the reported prevalence of HPV DNA in ESCC varies significantly among the published studies, ranging from 0 to $100 \%$, thus preventing any firm conclusions about an HPV-ESCC association $[14,20]$. Nevertheless, a growing number of researchers, including us, strongly believe that at least a subset of ESCC can be attributed to infection with oncogenic HPV types from the $\alpha-P V$ genus $[14,20,23]$. However, not everybody shares this opinion; e.g., a recent 13-page review on esophageal carcinoma published in the Lancet did not even mention HPV [16]. In addition, while the role of 12 oncogenic HPV types in the development of anogenital cancers and oropharyngeal cancer has been acknowledged by IARC [5], there is no similar consensus about a potential etiologic relationship between HPV and ESCC [23].

To the best of our knowledge, seven systematic reviews and/or meta-analyses of evidence for HPV involvement in etiopathogenesis of ESCC have been conducted to date $[13,14,20,22-25]$. The first formal review on this topic was published by our group in 1998 [24], followed by a review by Finish researchers in 2002 [25] and three consequent updates (in 2006, 2010 and 2012) by the same leading author $[13,20,22]$ and, finally, the last review and meta-analysis were published by Australian researchers in 2013 [14,23].

\section{The largest systematic review \& meta-analysis of studies reporting HPV prevalence in ESCC (1982-March 2012)}

To the best of our knowledge, the study published by Kari Syrjänen in 2012 [20] is the largest systematic review of studies reporting HPV prevalence in ESCC to date and the first formal meta-analysis of the subject. Using an extensive literature search through Medline/PubMed and Current Contents, a total of 152 studies from 32 different countries published from 1982 through March 2012 were selected and analyzed, out of 1177 abstracts found. Analyzed studies ranged from case series (most frequent category) and case reports through cross-sectional and some case-control studies. Based on the available data on geographic regions with different risks of ESCC, these studies were further categorized into the following regions of origin: China, other Asia, South Africa, South America, North Africa/Middle East, Australia, Europe and North America. In selecting appropriate studies, no restriction according to the method used for HPV detection was made, in order to validate the frequently presented opinion that the wide variation in HPV prevalence reported in ESCC is mainly due to the use of HPV detection methods with different sensitivities and specificities. Meta-regression was used to test the impact of study-level covariates (HPV detection method, geographic origin of study) on effect size, and potential publication bias was estimated using funnel plot symmetry.

According to the systematic review, a total of 10,234 ESCCs were tested until March 2012 for the presence of HPV, HPV antigens or HPV DNA, using various HPV detection and HPV typing methods, including histology assessment, IHC and various DNA hybridization and amplification techniques, mainly PCR. Out of 10,234 ESCCs analyzed, a total of 3135 (30.6\%) tested HPV DNA-positive, translating to an effect size of 0.372 (95\% CI: 0.360-0.384; fixed effects model) and 0.290 (95\% CI: 0.251-0.31; random effects model). When stratified by HPV detection method, there was a significant heterogeneity between the studies, but the betweenstrata summary comparison was not significant. In contrast, there was significant heterogeneity between the studies from the different geographic regions. In the maximum likelihood meta-regression, the HPV detection method was not a significant study-level covariate, in contrast to the geographic origin of the study, which had a significant impact on the summary effect size estimates $(p=0.00005)$. No evidence of significant publication bias was found by funnel plot symmetry testing. In the sensitivity analysis, all meta-analytic results appeared robust to all one-by-one study removals.

Stratification of studies by the region of origin showed that the highest HPV prevalence was generally observed in regions with a high incidence of ESCC: China $(40.1 \% ; 2268 / 5651)$, other Asian countries $(18.4 \%$; 412/2238), South Africa $(37.6 \% ; 176 / 468)$ and South America $(22.4 \% ; 80 / 357)$ and, accordingly, the lowest 
in regions with a low-incidence of ESCC, including Australia $(8.1 \% ; 22 / 271)$, North America $(8.0 \% ; 18 / 226)$, Europe $(14.0 \% ; 132 / 944)$ and Africa/Middle East (34.2\%; 27/79).

The author concluded that the reported wide variability in HPV detection rates in ESCC is not due to the use of HPV detection methods with different sensitivities and specificities, but is more likely explained by the geographic origin of the study. The largest systematic review to date and first meta-analysis substantiated the concept that ESCC might have a different etiology in low-incidence and high-incidence geographic regions, with HPV playing an important etiological role only in the latter.

\section{Update of the latest systematic review of studies reporting HPV prevalence in ESCC (1982-August 2013)}

Although, as just described, the latest systematic review of studies reporting HPV prevalence in ESCC was performed less than 2 years ago [20], the field is extremely productive, producing new important studies every month. We therefore repeated the literature search performed by Syrjänen in early 2012 (with slightly modified criteria) in order to produce the most updated list of all relevant studies dealing with HPV and ESCC published in the last 31 years. At the same time, in comparison to Syrjänen, we generated much more detailed information on the methods used for HPV detection/typing, and also produced a list of HPV types detected in all relevant studies published until the end of August 2013 (Supplementary Table 1; please see online at www.future-medicine.com/doi/full/10.2217/ fvl.13.116). Eligible peer-reviewed studies were identified by searching Medline/PubMed, Web of Science, Scopus and Google Scholar databases, and the reference lists of the original articles, reviews and meta-analyses investigating an ESCC-HPV association. The initial literature search was performed at the beginning of July 2013 and repeated again at the end of August 2013. The search terms included a combination of the following words: papillomavirus, HPV, esophagus, esophagus, cancer and carcinoma. The inclusion criteria for the studies were: at least one subject with a clinical condition of interest; country of origin provided; methodological description of HPV DNA detection/and typing methods used; and prevalence data provided for at least $\alpha-P V s$, and if available also for HPV16 and/or HPV-18. Of the identified duplicate (multiple) publications, only the chronologically first one was included in this review. No restrictions were placed on date of publication, language or methods used to detect HPV. The countries (regions) were determined as having high or low-medium incidence of ESCC according to the latest GLOBOCAN report in 2008 [10] and published literature $[14,20,23]$.

Using the above-specified selection criteria, a total of 159 studies published between 1982 and 2013 investigating the causal relationship between HPV and ESCC were considered eligible for the present analysis. As shown in Supplementary Table 1, of 159 eligible studies, 141 studies had been previously included and analyzed in the latest systematic review [20]. Eleven references included in the latest systematic review [20] were excluded from our analysis since they were recognized as duplicate publications, contained missing data about (HPV-positive) ESCC cases or had previously been counted twice. In the present literature search, we identified eight additional studies published from 1982 to 2011 [15,26-32] and ten novel studies that have been published in the last 2 years [33-42]. As shown in Supplementary Table 1, the 159 selected studies originated from five different continents: North America, South America, Europe, Africa, Asia and Australia; and 33 different countries: USA, Mexico, Colombia, Brazil, Chile, Venezuela, Sweden, Finland, France, Germany, Portugal, UK, Belgium, The Netherlands, Poland, Hungary, Italy, Slovenia, Bulgaria, Greece, Turkey, South Africa, Kenya, Egypt, Iran, Pakistan, China, Hong Kong, Taiwan, India, Korea, Japan and Australia.

Altogether, until August 2013 a total of 11,310 cases of ESCC had been analyzed in 159 studies using various HPV detection methods (ranging from early histology assessments and IHC to modern DNA hybridization and amplification techniques $)$ and a total of $30.3 \%(n=3424)$ ESCC specimens tested HPV positive (Table 1). As shown in Tables 1 \& 2, the highest HPV prevalence was generally observed in the regions having the highest incidence of ESCC. HPV DNA was thus detected in $39.1 \%$ of ESCC from China (range: $0-100 \%), 31.1 \%$ of ESCC from South Africa (range: $8.8-66.7 \%$ ) and $21.4 \%$ of ESCC from other Asian countries (range: $0-100 \%$ ). No HPV-positive ESCC cases were observed in East Africa (Kenya). In Asian countries (excluding China) the highest HPV DNA prevalence was detected in India (36\%) and Pakistan (26.2\%), 
Table 1. HPV DNA prevalence in esophageal squamous cell carcinoma according to geographic region (1982-2013).

\begin{tabular}{|c|c|c|c|c|c|c|c|}
\hline $\begin{array}{l}\text { Geographic } \\
\text { region }\end{array}$ & $\begin{array}{l}\text { Incidence } \\
\text { of ESCC } \\
\text { ASR (W) }\end{array}$ & $\begin{array}{l}\text { Risk of } \\
\text { ESCC }^{\ddagger}\end{array}$ & $\begin{array}{l}\text { Samples } \\
\text { tested (n) }\end{array}$ & $\begin{array}{l}\text { HPV positive } \\
\text { samples (n) }\end{array}$ & $\begin{array}{l}\text { Total HPV } \\
\text { positive } \\
(\%)\end{array}$ & $\begin{array}{l}\text { Range of HPV } \\
\text { positivity (\%) }\end{array}$ & $\begin{array}{l}\text { Scientific } \\
\text { reports }^{\S} \\
\text { (n) }\end{array}$ \\
\hline China & 16.7 & High & 6010 & 2348 & 39.0 & $0-100$ & 54 \\
\hline Other Asia & NA & High & 2391 & 511 & 21.4 & $0-100$ & 42 \\
\hline South Africa & 17.3 & High & 501 & 156 & 31.1 & $8.8-66.7$ & 11 \\
\hline $\begin{array}{l}\text { East Africa } \\
\text { (Kenya) }\end{array}$ & 13.4 & High & 29 & 0 & 0 & & 1 \\
\hline Australia & 3.4 & $\begin{array}{l}\text { Low- } \\
\text { medium }\end{array}$ & 271 & 22 & 8.1 & $3.6-50.0$ & 3 \\
\hline Europe & 3.3 & $\begin{array}{l}\text { Low- } \\
\text { medium }\end{array}$ & 1295 & 192 & 14.8 & $0-100$ & 33 \\
\hline South America & 4.0 & $\begin{array}{l}\text { Low- } \\
\text { medium }\end{array}$ & 413 & 90 & 21.8 & $0-100$ & 10 \\
\hline $\begin{array}{l}\text { North Africa } \\
\text { (Egypt) }\end{array}$ & 1.8 & $\begin{array}{l}\text { Low- } \\
\text { medium }\end{array}$ & 50 & 27 & 54.0 & & 1 \\
\hline North America & 3.3 & $\begin{array}{l}\text { Low- } \\
\text { medium }\end{array}$ & 350 & 78 & 22.3 & $0-100$ & 18 \\
\hline Total & & & 11,310 & 3424 & 30.3 & $0-100$ & 173 \\
\hline \multicolumn{8}{|c|}{$\begin{array}{l}\text { Incidence of ESCC given in ASR (W): age-standardized rate per 100,000 [10]. } \\
\text { FRisk of ESCC for individual geographic region (country) was set according to the latest GLOBOCAN report in } 2008 \text { [10] and } \\
\text { published literature }[14,20,23] \text {. } \\
\text { 5A total number of scientific reports extracted from } 159 \text { studies included in the analysis. } \\
\text { ASR (W): Age-adjusted incidence rate standardized for the world population; ESCC: Esophageal squamous cell carcinoma; NA: Not } \\
\text { available. }\end{array}$} \\
\hline
\end{tabular}

followed by Iran (24.9\%), Japan (18.0\%), Korea (15.1\%), Hong Kong (5.4\%) and Taiwan (3.2\%). In regions with low-to-medium risk of ESCC, the highest HPV DNA prevalence in ESCC was observed in North Africa (Egypt; 54.0\%), followed by North America (USA; 22.3\%; range: $0-100 \%)$, South America (21.8\%; range: 0-100\%), Europe (14.8\%; range: $0-100 \%)$ and Australia (8.1\%; range: 3.6-50.0\%). In South America, the highest HPV DNA prevalence was detected in Venezuela (100\%), followed by Mexico (39.0\%), Colombia (24.5\%), Chile (19.2\%) and Brazil (13.6\%). In Europe, the highest HPV DNA prevalence was observed in Turkey (63.3\%), Greece (56.7\%) and Portugal $(56.3 \%)$, and the lowest in The Netherlands $(0 \%)$, Slovenia (1.4\%) and France $(3.5 \%)$. The mean HPV DNA prevalence in the other nine European countries ranged from 3.7 to $50.0 \%$ (Table 2). In South American and European countries, no correlation was observed between HPV DNA prevalence and the incidence rate of ESCC (Table 2).

A review of HPV type-specific prevalence in ESCC (2008-August 2013)

According to the Future Medicine Author Guidelines, we evaluated studies published in the last 5 years in more detail. HPV detection and typing methods used in these studies were evaluated in great detail, as well as HPV typespecific distribution data and the age of patients. Thus, in addition to the parameters described above, we also specifically calculated HPV-16/18 type-specific positivity as a proportion of HPV-16/-18-positive cases among all cancers tested for HPV DNA and a proportion of HPV16/-18-positive cases among all cancers tested positive for HPV DNA (Table 3). To estimate the proportions of ESCC attributed to HPV-16 and HPV-18, the proportional attribution model [43] was used for most of the analyzed studies. Exact HPV type-specific distribution data for the first time allowed a precise estimation of the potential global and local benefit of prophylactic HPV vaccination with the currently available, as well as second-generation HPV vaccines, although only if proved also to work against nongenital HPV-related cancers or their precursors.

As shown in Table 3, a total of 42 eligible studies investigating HPV prevalence/type distribution in patients with ESCC were published in the last 5 years [29-42,44-71]. Altogether, a total of 4014 patients with ESCC (from 17 counties, five continents) were tested using various HPV molecular assays, ranging from commercial 
Table 2. HPV DNA prevalence in esophageal squamous cell carcinoma according to country of origin (1982-2013).

\begin{tabular}{|c|c|c|c|c|c|c|c|}
\hline Country & $\begin{array}{l}\text { Incidence } \\
\text { of ESCC } \\
\text { ASR }(W)\end{array}$ & $\begin{array}{l}\text { Risk of } \\
\text { ESCC }^{\ddagger}\end{array}$ & $\begin{array}{l}\text { Total } \\
\text { samples } \\
\text { (n) }\end{array}$ & $\begin{array}{l}\text { HPV } \\
\text { positive } \\
\text { samples (n) }\end{array}$ & $\begin{array}{l}\text { Total HPV } \\
\text { positive } \\
\text { (\%) }\end{array}$ & $\begin{array}{l}\text { Range of } \\
\text { HPV } \\
\text { positivity (\%) }\end{array}$ & $\begin{array}{l}\text { Scientific } \\
\text { reports }^{\S}(n)\end{array}$ \\
\hline \multicolumn{8}{|l|}{ Other Asia } \\
\hline Iran & 6.8 & High & 718 & 179 & 24.9 & $0-49.4$ & 9 \\
\hline Japan & 5.7 & High & 974 & 176 & 18.0 & $0-63.0$ & 19 \\
\hline India & 5.3 & High & 289 & 104 & 36.0 & 18.7-100 & 6 \\
\hline Hong Kong & NA & High & 112 & 6 & 5.4 & $0-8$ & 2 \\
\hline Taiwan & 6 & High & 31 & 1 & 3.2 & & 1 \\
\hline Pakistan & 5.9 & NA & 42 & 11 & 26.2 & & 1 \\
\hline Korea & 3.1 & $\begin{array}{l}\text { Low- } \\
\text { medium }\end{array}$ & 225 & 34 & 15.1 & $0-66.7$ & 4 \\
\hline Total & & & 2391 & 511 & 21.4 & $0-100$ & 42 \\
\hline \multicolumn{8}{|l|}{ Europe } \\
\hline Belgium & 4.9 & $\begin{array}{l}\text { Low- } \\
\text { medium }\end{array}$ & 23 & 3 & 13.0 & $4.8-100$ & 3 \\
\hline Bulgaria & 1.5 & $\begin{array}{l}\text { Low- } \\
\text { medium }\end{array}$ & 4 & 1 & 25.0 & & 1 \\
\hline Finland & 2.1 & $\begin{array}{l}\text { Low- } \\
\text { medium }\end{array}$ & 121 & 35 & 28.9 & $18.0-40.0$ & 2 \\
\hline France & 3.9 & $\begin{array}{l}\text { Low- } \\
\text { medium }\end{array}$ & 171 & 6 & 3.5 & $0-41.7$ & 5 \\
\hline Germany & 3.8 & $\begin{array}{l}\text { Low- } \\
\text { medium }\end{array}$ & 76 & 9 & 11.8 & $0-17.0$ & 2 \\
\hline Greece & 0.8 & $\begin{array}{l}\text { Low- } \\
\text { medium }\end{array}$ & 30 & 17 & 56.7 & & 1 \\
\hline Hungary & 3.8 & $\begin{array}{l}\text { Low- } \\
\text { medium }\end{array}$ & 26 & 6 & 23.1 & & 1 \\
\hline Italy & 1.9 & $\begin{array}{l}\text { Low- } \\
\text { medium }\end{array}$ & 136 & 20 & 14.7 & $0-47.0$ & 5 \\
\hline Poland & 2.3 & $\begin{array}{l}\text { Low- } \\
\text { medium }\end{array}$ & 56 & 28 & 50.0 & & 1 \\
\hline Portugal & 3.5 & $\begin{array}{l}\text { Low- } \\
\text { medium }\end{array}$ & 16 & 9 & 56.3 & & 1 \\
\hline Slovenia & 2.5 & $\begin{array}{l}\text { Low- } \\
\text { medium }\end{array}$ & 141 & 2 & 1.4 & $0-10.0$ & 2 \\
\hline Sweden & 2.0 & $\begin{array}{l}\text { Low- } \\
\text { medium }\end{array}$ & 314 & 36 & 11.5 & $0-16.0$ & 3 \\
\hline $\begin{array}{l}\text { The } \\
\text { Netherlands }\end{array}$ & 5.8 & $\begin{array}{l}\text { Low- } \\
\text { medium }\end{array}$ & 124 & 0 & 0 & & 2 \\
\hline Turkey & 4.8 & $\begin{array}{l}\text { Low- } \\
\text { medium }\end{array}$ & 30 & 19 & 63.3 & & 1 \\
\hline UK & 6.4 & $\begin{array}{l}\text { Low- } \\
\text { medium }\end{array}$ & 27 & 1 & 3.7 & $0-100$ & 3 \\
\hline Total & & & 1295 & 192 & 14.8 & $0-100$ & 33 \\
\hline \multicolumn{8}{|c|}{ South America } \\
\hline Brazil & 5.1 & $\begin{array}{l}\text { Low- } \\
\text { medium }\end{array}$ & 206 & 28 & 13.6 & $2.5-100$ & 3 \\
\hline \multicolumn{8}{|c|}{$\begin{array}{l}\text { Incidence of esophageal squamous cell carcinoma given in ASR (W): age-standardized rate per 100,000 [10]. } \\
\text { *Risk of ESCC for individual geographic region (country) was set according to the latest GLOBOCAN report in } 2008[10] \text { and } \\
\text { published literature }[14,20,23] \text {. } \\
\text { \$A total number of scientific reports extracted from } 159 \text { studies included in the analysis. } \\
\text { ASR (W): Age-adjusted incidence rate standardized for the world population; ESCC: Esophageal squamous cell carcinoma; NA: Not } \\
\text { available. }\end{array}$} \\
\hline
\end{tabular}




\begin{tabular}{|c|c|c|c|c|c|c|c|}
\hline Country & $\begin{array}{l}\text { Incidence } \\
\text { of ESCC } \\
\text { ASR }(W)\end{array}$ & $\begin{array}{l}\text { Risk of } \\
\text { ESCC }^{\ddagger}\end{array}$ & $\begin{array}{l}\text { Total } \\
\text { samples } \\
\text { (n) }\end{array}$ & $\begin{array}{l}\text { HPV } \\
\text { positive } \\
\text { samples (n) }\end{array}$ & $\begin{array}{l}\text { Total HPV } \\
\text { positive } \\
\text { (\%) }\end{array}$ & $\begin{array}{l}\text { Range of } \\
\text { HPV } \\
\text { positivity (\%) }\end{array}$ & $\begin{array}{l}\text { Scientific } \\
\text { reports }^{\S}(n)\end{array}$ \\
\hline \multicolumn{8}{|c|}{ South America (cont.) } \\
\hline Chile & 4.3 & $\begin{array}{l}\text { Low- } \\
\text { medium }\end{array}$ & 26 & 5 & 19.2 & & 1 \\
\hline Colombia & 2.2 & $\begin{array}{l}\text { Low- } \\
\text { medium }\end{array}$ & 102 & 25 & 24.5 & $0-34.0$ & 3 \\
\hline Mexico & 1.3 & $\begin{array}{l}\text { Low- } \\
\text { medium }\end{array}$ & 77 & 30 & 39.0 & $25.0-88.2$ & 2 \\
\hline Venezuela & 1.5 & $\begin{array}{l}\text { Low- } \\
\text { medium }\end{array}$ & 2 & 2 & 100 & & 1 \\
\hline \multicolumn{3}{|l|}{ Total } & 413 & 90 & 21.8 & $0-100$ & 10 \\
\hline \multicolumn{8}{|c|}{$\begin{array}{l}\text { †ncidence of esophageal squamous cell carcinoma given in ASR (W): age-standardized rate per 100,000 [10]. } \\
\text { FRisk of ESCC for individual geographic region (country) was set according to the latest GLOBOCAN report in 2008 [10] and } \\
\text { published literature [14,20,23]. } \\
\text { SA total number of scientific reports extracted from } 159 \text { studies included in the analysis. } \\
\text { ASR (W): Age-adjusted incidence rate standardized for the world population; ESCC: Esophageal squamous cell carcinoma; NA: Not } \\
\text { available. }\end{array}$} \\
\hline
\end{tabular}

$\alpha$-PV DNA-based assays to various in-house consensus primer-mediated or HPV type-specific PCRs. In some studies, the in-situ hybridization (ISH) technique was applied to detect $\alpha-P V$ using various commercial or in-house consensus or HPV type-specific hybridization probes. As shown in Table 3, the overall $\alpha-P V$ DNA prevalence recorded in the studies published in the last 5 years was $32.2 \%$ (1291/4014), ranging from 0 to $100.0 \%$ in individual studies. The calculated mean HPV prevalence in studies published in the last 5 years was similar to those obtained in the latest systematic review, which included 10,234 patients with ESCC [20], as well as in our update presented here, which included 11,310 patients with ESCC. The mean age of patients at diagnosis of ESCC, estimated from 12 studies with available data, was 61.3 years (mean age range: $53.0-69.5$ years; Table 3 ).

The calculated combined HPV-16/-18 prevalence, assessed on a total of 3203 ESCC from 26 eligible studies [29,33-38,41,44-46,48-51,53-55,58,60,61,65-68,70], was 23.2 and $73.7 \%(743 / 1008)$ among all HPV DNA-positive cases, respectively. For 27 and 24 studies, respectively, separate HPV-16 and HPV18 type-specific prevalence data were available (Table 3). Altogether, HPV-16 was found in 16.3\% (457/2807; range: $0-100 \%$ ) and HPV-18 in 2.7\% (72/2645; range: $0-22.2 \%$ ) of the investigated cases of ESCC. To the best of our knowledge, this is the first extensive estimation of HPV16/-18 prevalence among patients with ESCC. Our results clearly showed that prophylactic vaccination with currently available $\mathrm{HPV}$ vaccines could theoretically prevent more that $70 \%$ of all $\alpha$-PV DNA-positive ESCC, a figure similar to cervical cancer.

In addition to HPV-16 and/or HPV-18 type-distribution data, a number of studies $[33-35,37,38,44,51,54-56,58,60,65,67,70]$ also reported the detailed distribution of other HPV types, which originated predominantly from the $\alpha-P V$ genus. Thus, in addition to HPV-16 and HPV18 , the following $\alpha-P V$ types were detected at least once in patients with ESCC (either presenting as single or multiple infections): HPV-3, -6, $-11,-26,-27,-31,-33,-35,-39,-42,-44,-45$, $-51,-52,-54,-56,-57,-58,-59,-66,-73,-82$, $-89,-91,-94$ and -97 . The prevalence of multiple HPV types among HPV DNA-positive ESCC recorded in four studies ranged from 15.8 to $54.2 \%[35,55,65,67]$.

In three studies from India, Iran and Poland $[34,35,38]$, the reported prevalence of HPV types other than HPV-16 and HPV-18 was surprisingly higher than the combined prevalence of HPV-16/-18. Specifically, in a study performed in India in which 20/23 ESCC were HPV DNA-positive, HPV-52 was the most commonly observed type, followed by HPV55 (subHPV-44), -39 and -59; and only four cases contained HPV-16 and/or HPV-18 [34]. In the Iranian study [35], using real-time PCR typing, a total of $14 \mathrm{HPV}$ types were detected among 49/177 HPV DNA-positive cases; the most prevalent types were HPV-11 and -45, followed by HPV-6, -52 and -39; only two cases 


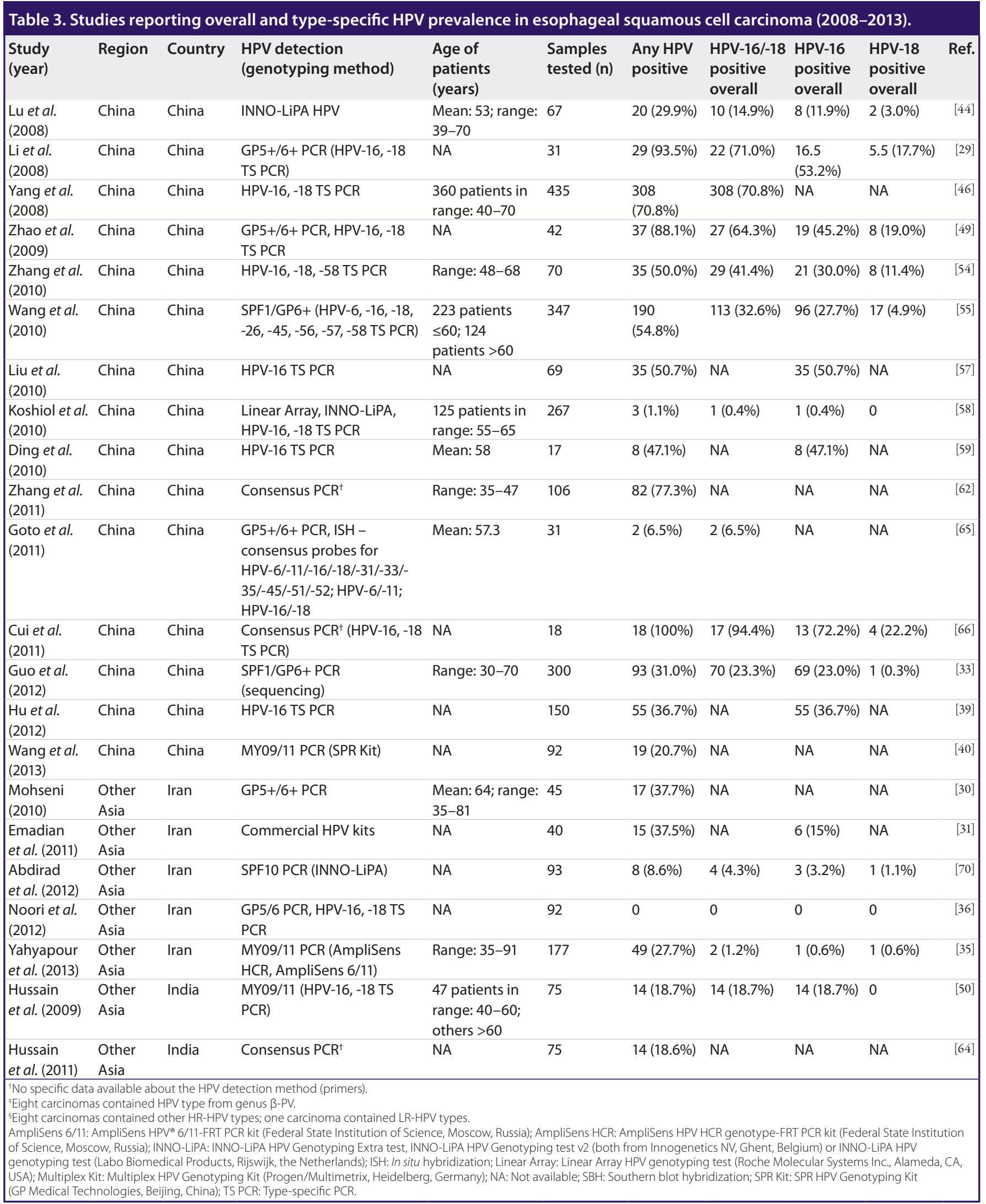


Table 3. Studies reporting overall and type-specific HPV prevalence in esophageal squamous cell carcinoma (2008-2013) (cont.).

\begin{tabular}{|c|c|c|c|c|c|c|c|c|c|c|}
\hline $\begin{array}{l}\text { Study } \\
\text { (year) }\end{array}$ & Region & Country & $\begin{array}{l}\text { HPV detection } \\
\text { (genotyping method) }\end{array}$ & $\begin{array}{l}\text { Age of } \\
\text { patients } \\
\text { (years) }\end{array}$ & $\begin{array}{l}\text { Samples } \\
\text { tested (n) }\end{array}$ & $\begin{array}{l}\text { Any HPV } \\
\text { positive }\end{array}$ & $\begin{array}{l}\text { HPV-16/-18 } \\
\text { positive } \\
\text { overall }\end{array}$ & $\begin{array}{l}\text { HPV-16 } \\
\text { positive } \\
\text { overall }\end{array}$ & $\begin{array}{l}\text { HPV-18 } \\
\text { positive } \\
\text { overall }\end{array}$ & Ref. \\
\hline $\begin{array}{l}\text { Gupta et al. } \\
\text { (2012) }\end{array}$ & $\begin{array}{l}\text { Other } \\
\text { Asia }\end{array}$ & India & MY09/11 PCR & NA & 49 & 17 (34.7\%) & NA & NA & NA & [71] \\
\hline $\begin{array}{l}\text { Vaiphei et al. } \\
\text { (2012) }\end{array}$ & $\begin{array}{l}\text { Other } \\
\text { Asia }\end{array}$ & India & Linear Array & Range: 37-78 & 23 & $20(87.0 \%)$ & $4(17.4 \%)$ & $3(13.0 \%)$ & $1(4.4 \%)$ & [34] \\
\hline $\begin{array}{l}\text { Goto et al. } \\
\text { (2011) }\end{array}$ & $\begin{array}{l}\text { Other } \\
\text { Asia }\end{array}$ & Japan & $\begin{array}{l}\text { GP5+/6+ PCR, ISH - } \\
\text { consensus probes for } \\
\text { HPV-6/-11/-16/-18/-31/-33/- } \\
\text { 35/-45/-51/-52; HPV-6/-11; } \\
\text { HPV-16/-18 }\end{array}$ & Range: $51-75$ & 76 & $8(10.5 \%)$ & $6(7.9 \%)$ & NA & NA & {$[6$} \\
\hline $\begin{array}{l}\text { Castillo et al. } \\
\text { (2011) }\end{array}$ & $\begin{array}{l}\text { Other } \\
\text { Asia }\end{array}$ & Japan & SPF1/2 PCR (INNO-LiPA) & $\begin{array}{l}\text { Mean: 64; range: } \\
62-65\end{array}$ & 75 & $11(14.6 \%)$ & $9(12.0 \%)$ & $\begin{array}{l}8.5 \\
(11.3 \%)\end{array}$ & $0.5(0.7 \%)$ & 16 \\
\hline $\begin{array}{l}\text { Koh et al. } \\
(2008)\end{array}$ & $\begin{array}{l}\text { Other } \\
\text { Asia }\end{array}$ & Korea & CP PCR [79], HPV-16 TS PCR & $\begin{array}{l}\text { Mean: } 62.3 ; \\
\text { range: } 39-81\end{array}$ & 102 & 0 & 0 & 0 & 0 & {$[4$} \\
\hline $\begin{array}{l}\text { Goto et al. } \\
\text { (2011) }\end{array}$ & $\begin{array}{l}\text { Other } \\
\text { Asia }\end{array}$ & Korea & $\begin{array}{l}\text { GP5+/6+ PCR, ISH - } \\
\text { consensus probes for } \\
\text { HPV-6/-11/-16/-18/-31/-33/- } \\
\text { 35/-45/-51/-52; HPV-6/-11; } \\
\text { HPV-16/-18 }\end{array}$ & Mean: 62.1 & 74 & $7(9.5 \%)$ & $5(6.8 \%)$ & NA & NA & \\
\hline $\begin{array}{l}\text { Castillo et al. } \\
\text { (2011) }\end{array}$ & $\begin{array}{l}\text { Other } \\
\text { Asia }\end{array}$ & Pakistan & SPF1/2 PCR (INNO-LiPA) & $\begin{array}{l}\text { Mean: } 54 \text {; range: } \\
50-57\end{array}$ & 42 & $11(26.2 \%)$ & $10(23.8 \%)$ & $9(21.4 \%)$ & $1(2.4 \%)$ & [67] \\
\hline $\begin{array}{l}\text { Schäfer et al. } \\
\text { (2013) }\end{array}$ & $\begin{array}{l}\text { South } \\
\text { Africa }\end{array}$ & $\begin{array}{l}\text { South } \\
\text { Africa }\end{array}$ & $\begin{array}{l}\text { MY09/11 nested with } \\
\text { GP5+/6+ (sequencing) }\end{array}$ & NA & 114 & $10(8.8 \%)$ & NA & NA & $8(7.0 \%)$ & 42] \\
\hline $\begin{array}{l}\text { Antonsson } \\
\text { et al. (2010) }\end{array}$ & Australia & Australia & GP5+/6+ (sequencing) & Mean: 65.2 & 222 & $8(3.6 \%)$ & $6(2.7 \%)$ & $6(2.7 \%)$ & 0 & 60] \\
\hline $\begin{array}{l}\text { Bognar et al. } \\
(2008)\end{array}$ & Europe & Hungary & HPV-16, -18 TS PCR and SBH & NA & 26 & $6(23.1 \%)$ & NA & NA & NA & 47] \\
\hline $\begin{array}{l}\text { Tornesello } \\
\text { et al. (2009) }\end{array}$ & Europe & Italy & $\begin{array}{l}\text { MY09/11 nested with } \\
\text { GP5+/6+ (sequencing), } \\
\text { CP65/70 nested with } \\
\text { CP66/69 (sequencing), } \\
\text { FAP59/64 (sequencing), } \\
\text { HPV-16, -38 TS PCR }\end{array}$ & Mean: 61.3 & 36 & $10^{\ddagger}(27.8 \%)$ & $1(2.8 \%)$ & $1(2.8 \%)$ & 0 & [48] \\
\hline $\begin{array}{l}\text { Erol et al. } \\
\text { (2009) }\end{array}$ & Europe & Bulgaria & $\begin{array}{l}\text { GP5/6 (HPV-11, -16, -18, }-33 \\
\text { TS PCR) }\end{array}$ & NA & 4 & $1(25.0 \%)$ & NA & NA & NA & 52] \\
\hline $\begin{array}{l}\text { Löfdahl et al. } \\
\text { (2012) }\end{array}$ & Europe & Sweden & $\begin{array}{l}\text { BGP5+/6+ PCR (Multiplex } \\
\text { Kit) }\end{array}$ & $\begin{array}{l}167 \text { patients } \\
\geq 60 \text { years }\end{array}$ & 204 & $20^{5}(9.8 \%)$ & $13(6.4 \%)$ & $13(6.4 \%)$ & 0 & [37] \\
\hline $\begin{array}{l}\text { Dabrowski } \\
\text { et al. (2012) }\end{array}$ & Europe & Poland & MY09/11 PCR (sequencing) & $\begin{array}{l}\text { Range: } 49.0- \\
67.0\end{array}$ & 56 & $28(50 \%)$ & $5(8.9 \%)$ & NA & NA & [38] \\
\hline $\begin{array}{l}\text { Herrera- } \\
\text { Goepfert } \\
\text { et al. (2009) }\end{array}$ & $\begin{array}{l}\text { South } \\
\text { America }\end{array}$ & Mexico & $\begin{array}{l}\text { L1C1/2 (sequencing), } \\
\text { MY09/11 (sequencing), } \\
\text { GP5/6 (sequencing), HPV-16, } \\
\text {-18 TS PCR }\end{array}$ & Range: $27-85$ & 60 & 15 (25.0\%) & $11(18.3 \%)$ & $6(10.0 \%)$ & $5(8.3 \%)$ & [51] \\
\hline $\begin{array}{l}\text { Castillo et al. } \\
\text { (2011) }\end{array}$ & $\begin{array}{l}\text { South } \\
\text { America }\end{array}$ & Colombia & $\begin{array}{l}\text { SPF1/2 PCR, HPV16 TS PCR } \\
\text { (INNO-LiPA) }\end{array}$ & $\begin{array}{l}\text { Mean: 64; range: } \\
60-67\end{array}$ & 49 & $9(18.4 \%)$ & 9 (18.4\%) & $5(10.2 \%)$ & $4(8.2 \%)$ & [67] \\
\hline $\begin{array}{l}\text { Mancilia } \\
\text { et al. (2011) }\end{array}$ & $\begin{array}{l}\text { South } \\
\text { America }\end{array}$ & Colombia & HPV-16 TS PCR & $\begin{array}{l}4 \text { patients } \geq 65 \\
\text { years }\end{array}$ & 6 & 0 & 0 & 0 & 0 & [32] \\
\hline $\begin{array}{l}\text { De Oliveira } \\
\text { Mota et al. } \\
(2013)\end{array}$ & $\begin{array}{l}\text { South } \\
\text { America }\end{array}$ & Brazil & $\begin{array}{l}\text { GP5+/6+ PCR (INNO-LiPA, } \\
\text { HPV-16 TS PCR) }\end{array}$ & 74 & 1 & $1(100 \%)$ & $1(100 \%)$ & $1(100 \%)$ & 0 & [41] \\
\hline \multicolumn{11}{|c|}{ 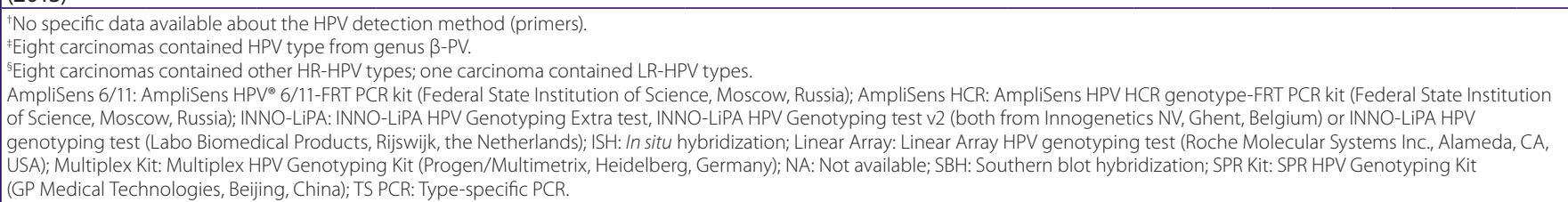 } \\
\hline
\end{tabular}




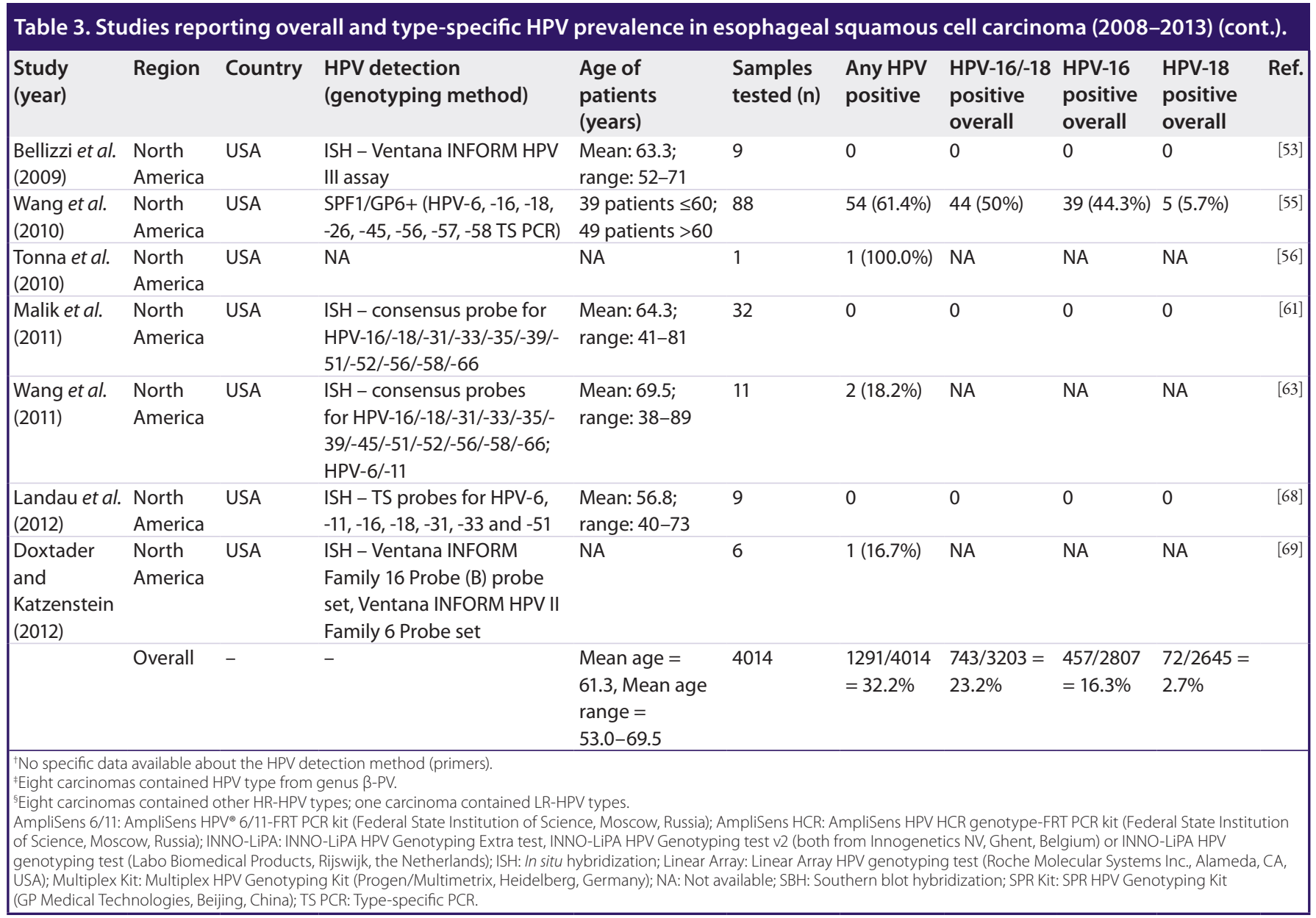

contained HPV-16 and/or HPV-18. The Polish study surprisingly detected HPV DNA in 28/56 ESCC: HPV-16/-18 were found in five cases (8.9\%), low-risk HPVs (no detailed data available about HPV types detected) in 19 (33.9\%) and other HPV types (HPV-37, -81, -89 and $-97)$ in four cases (7.1\%). These data further confirm the existence of regional differences in HPV type distribution in ESCC, suggesting that second-generation prophylactic HPV vaccines covering a broader spectrum of HPV types may perform better in reducing the global burden of this disease.

In a recent study performed in Italy [48], using several HPV genera-specific broad-range PCR assays, $10 / 36$ cases (27.8\%) of ESCC were HPV DNA-positive, of which eight harbored officially recognized or putatively novel $\beta$-PV types, including HPV-8, -20, -25, CJ198, X15, DL473, PPHL1FR and X14. HPV types from the genus $\beta-P V$, which are typically isolated from skin and hair follicle specimens, have been associated with cutaneous squamous cell carcinomas in immunosuppressed individuals, including patients with Epidermodysplasia verruciformis or organ transplantation, as well as in the immunocompetent population [72]. Moreover, recent reports indicate that HPV types from the $\beta-P V$ genus can also infect the mucosal epithelium of the head and neck region, including oral and nasal cavity and larynx [4,73-75], as well as the mucocutaneous epithelium of the anal canal/ edge [4], indicating a broader spectrum of epithelial tropism than previously appreciated for $\beta$-PVs. However, the implication of $\beta$-PV types in the etiopathogenesis of nonskin human malignancies including ESCC remains elusive.

\section{Meta-analysis of 21 case-control studies} investigating the etiological role of HPV in the development of ESCC (1991-2010)

In contrast to Syrjänen's [20] and our approach, in which the whole published literature corpus was analyzed, Australian researchers recently adopted a different way of investigating the etiological role of HPV in the development of 
ESCC by analyzing only case-control studies; e.g., studies in the literature that compared HPV rates in ESCC patients and healthy control subjects without ESCC. This was done in two steps, by performing a literature review and analysis of individual studies [14], followed by the first global meta-analysis of all case-control studies investigating a potential association between HPV and ESCC [23].

Their search through Medline/PubMed and EMBASE databases of literature published from 1991 to 2010 identified 139 studies, of which 22 were case-control studies [14]. The great majority of case-control studies were very small, the largest of which tested 265 cases and 357 controls. Two studies found no evidence of HPV in either the ESCC patients or the control groups. In most studies, HPV detection rates were higher in ESCC cases than in the control group, although three studies reported a higher percentage of control tissue with HPV infection relative to ESCC samples. Univariate crude odds ratios (ORs) with $95 \% \mathrm{CI}$ and p-values for the risk of ESCC associated with HPV was calculated for each of the 22 case-control studies. Nine studies had ORs that showed a significant association between HPV and ESCC [14], and for the largest single case-control study the OR was 2.71 (95\% CI: 1.86-3.94; $\mathrm{p}<0.001$ ) [76]. Interestingly, although all studies presented data from which a measure of association such as OR could be calculated, only two papers presented an OR calculated by the authors, highlighting the lack of multi-disciplinary and methodological expertise in the majority of published case-control studies [23].

In the further step, the Australian researchers postulated that, in the absence of cohort studies as well as a large, adequately powered single case-control study, a meta-analysis of all available (small) case-control studies is at present the most rigorous way of identifying any potential association between HPV and ESCC [23]. The first global meta-analysis of published case-control studies was thus performed, which included a total of 1223 patients with ESCC and 1415 control subjects enrolled in 21 eligible case-control studies performed to date [23]. HPV detection rates were tabulated for each study and all studies were assessed for quality. Generally, using IHC, ISH and/or PCR methodology, HPV DNA $(\alpha-P V)$ was detected in a significantly higher proportion of ESCC samples (35\%) than control samples (27\%). Meta-analysis showed a strong positive association between HPV infection and the development of ESCC; the calculated pooled OR obtained from random effects analysis was 3.042 (95\% CI: 2.2-4.2). Metaregression analysis did not find a significant association between OR and any of the quality domains. Influence analysis was nonsignificant for the effect of individual studies on the pooled estimate. In addition, there was no evidence of publication bias. Interestingly, countries with a low-medium incidence of ESCC, including Greece, the USA and Australia, showed a stronger relationship between HPV infection and ESCC development (OR: 4.65; 95\% CI: 2.47-8.76) than regions with a high-incidence of ESCC (e.g., China, Iran and South Africa; OR: 2.65; 95\% CI: 1.80-3.91). The authors believe that the inclusion of only relevant casecontrol studies increased resources, and the more advanced laboratory techniques and methodologies used for investigation in high-income countries could explain the observed differences in HPV detection rates and the region-specific HPV-ESCC association between their metaanalysis and previous systemic reviews. Another very interesting and unexpected finding was that while all studies showed a positive correlation between HPV and ESCC, the association was stronger in earlier studies than in later studies.

Although this meta-analysis provides the strongest evidence to date of an HPV-ESCC association, suggesting that HPV increases the risk of ESCC threefold, the meta-analysis had several important limitations. First, most of the selected case-control studies did not measure potential confounders or effect modifiers, or adjust for their effects. Age, gender, smoking, alcohol consumption, family history of esophageal cancer, pre-existing immunosuppression prior to cancer diagnosis, a history of thoracic irradiation, socio-economic status, diets high in red and processed meat, consumption of hot food and beverages, pickled foods, and diets low in fresh fruit and vegetables are all confounding for effect-modifying actors, which may have an impact on the analysis of a HPV-ESCC link. Another significant limitation of meta-analysis was the varying ratio of cases to controls in the selected studies, which suggest ad-hoc or convenience-based design rather than carefully planned study designs. To control for bias, the quality of each study included in the meta-analysis was assessed according to a specific scoring instrument with a maximum score of 100 
points. The total average percentage for quality assessment for all 21 case-control studies was 46 ; the range was 22-67.

\section{Conclusion}

In 2008, esophageal cancer was the eighth most common cancer and the sixth most common cause of death from cancer. Esophageal cancer shows remarkable regional variations in the incidence rates but the reasons for these variations are poorly understood, as is esophageal cancer's etiology. The etiology of the most common type of esophageal cancer - ESCC - is indisputably multifactorial and includes a synergistic action of officially recognized IARC group 1 human carcinogens: tobacco, betel quid with or without added tobacco, alcohol and acetaldehyde associated with alcoholic beverages, and probably several other not yet officially confirmed carcinogens. According to the robust and strong data that have accumulated recently and have been summarized here, certain carcinogenic HPV types from the $\alpha$-PV genus should also be seriously considered as etiological agents for at least a subset of ESCC.

The first formal meta-analysis of all studies reporting HPV prevalence in ESCC from 1982 until March 2012 [20], and our update of literature published until August 2013 (presented here), identified 159 studies with a total of 11,310 cases of ESCC analyzed for the presence of HPV. Both analyses showed the presence of HPV in almost one third of ESCC tissue specimens. However, HPV DNA detection rates were highly variable in different geographical areas of the world, being generally higher in high-incidence ESCC areas than in those with a low-incidence of ESCC. There has been some speculation as to why HPV DNA detection rates in ESCC specimens are higher in highincidence ESCC areas. Australian researchers recently proposed that this is simply a reflection of the fact that HPV infection rates in general are higher in developing than in developed countries [14]. Impoverished parts of the world, in which citizens have low education levels, poor nutrition and limited access to healthcare facilities, may account for the higher incidence rate of HPV infection among them and this may, in turn, translate to higher HPV detection rates also in ESCC specimens from these regions [14]. However, the situation is not black and white. Although in general studies conducted in high-incidence regions have reported higher
HPV detection rates in ESCC specimens than studies carried out in low-incidence regions, and the majority of the most recent studies have continued to support this trend (Table 3), there have been some exceptions to this pattern. For example, some recent reports from China [58], Iran [70] and Japan [65], all high-incidence countries, identified HPV in less than one tenth of their ESCC specimens, and vice versa, some recent studies conducted in populations from low-incidence regions have demonstrated relatively high HPV detection rates in ESCC tissue specimens (Tables 2 \& 3 ).

Although, as recently stressed by Australian researchers [23], suboptimal study design, heterogeneous and small-scale studies, inconsistent laboratory methods for HPV detection and variations in specimen retrieval and storage have all synergistically contributed to the lack of clarity and inability to resolve the question of whether HPV plays a role in the etiology of ESCC, the main problem probably lies in the fact that the great majority of the $150+$ published studies are indeed case series studies that are by design unable to answer questions of etiology, because a measure of association cannot be calculated without a control group. Thus, in the absence of cohort studies and an appropriately powered single case-control study, a meta-analysis of several small unpowered case-control studies was the only hope of extracting solid evidence of an HPV-ESCC link from published data. Indeed, meta-analysis of 21 eligible case-control studies showed a significant, robust and strong positive association between HPV infection and the development of ESCC, suggesting that HPV increases the risk of ESCC at least threefold.

Our literature review clearly showed that the two most important vaccine-preventable HPV types - HPV-16 and HPV-18 - have been the most commonly identified HPV types in ESCC specimens in both low-incidence and high-incidence settings. Prophylactic vaccination with both currently available HPV vaccines could thus theoretically prevent more that $70 \%$ of all $\alpha$-PV DNA-positive ESCC, a figure similar to that for cervical cancer [77]. Although several small case-control studies, as well as the meta-analysis of all available case-control studies, undoubtedly support an etiological role of HPV in a subset of ESCC [23], due to a lack of undisputed evidence that HPV is a definitive causative factor in ESCC and the lack of direct evidence of the efficacy of HPV vaccines against 
nongenital HPV-related cancers or their precursors, the promotion of an HPV vaccination for the general population with a view to preventing ESCC cannot be justified at present.

\section{Future perspective}

In order to provide conclusive evidence that HPV is a definitive causative factor in ESCC, as the HPV community has already done for cervical, anal and some other anogenital cancers [6], we clearly need more well-designed and better powered studies. In our opinion, after two formal meta-analysis and several recent systemic reviews, we cannot expect to extract more solid and robust evidence from already existing literature. Cohort studies are theoretically the best approach, but this is not feasible due to the long follow-up required for the development of ESCC and the difficulty of determining exposure status to HPV in such a study [23].

A large, well-designed case-control study with sufficient power indisputably to ascertain HPV rates in ESCC cases compared with controls without ESCC is the most practical and probably the only way forward. The proposed case-control study should preferably be an international collaboration putting together the best researchers from all continents, and should use a mandatory uniform HPV DNA (and possibly HPV RNA) testing methodology for all tissue samples. One successful example of such international collaboration is a recent study in which 10,575 cases of invasive cervical cancer collected from 38 countries in Europe, North America, central South

\section{EXECUTIVE SUMMARY}

\section{Human papillomaviruses \& human cancers}

- Human papillomaviruses (HPVs) are the most important viral etiological agents of human cancers. Twelve types from the HPV $\alpha$-PV genus are officially recognized as group 1 human carcinogens etiologically linked with virtually all cases of cervical cancer, and a substantial proportion of anal, vaginal, penile, vulvar and oropharyngeal carcinomas.

\section{Etiology of esophageal cancer}

- Esophageal cancer is the eighth most common cancer, which shows remarkable regional variations in incidence rates. The etiology of the most common type of esophageal cancer - esophageal squamous cell carcinoma (ESCC) - is undisputedly multifactorial and includes the synergistic action of group 1 human carcinogens: tobacco, betel quid with or without added tobacco, alcohol and acetaldehyde associated with alcoholic beverages.

\section{HPV \& esophageal cancer}

- According to the robust and strong data which has accumulated recently, carcinogenic HPV types from the $\alpha-P V$ genus, mainly HPV-16, should also be seriously considered as etiological agents for at least a subset of ESCC.

- Recent meta-analysis of all studies reporting HPV prevalence in ESCC and our literature update (1982-August 2013) identified 159 studies with a total of 11,310 cases of ESCC analyzed for the presence of HPV. A total of $30.3 \%$ ESCC specimens tested HPV positive. HPV DNA detection rates were highly variable in different geographical areas of the world.

- A meta-analysis of 21 case-control studies investigating the etiological role of HPV in the development of ESCC (1991-2010) provides the strongest evidence to date of an HPV-ESCC association. It undoubtedly showed that HPV increases the risk of ESCC at least threefold.

\section{Prophylactic HPV vaccines}

- Two most important vaccine-preventable HPV types - HPV-16 and HPV-18 - are the most commonly identified HPV types in ESCC specimens in both low-incidence and high-incidence settings. Prophylactic vaccination with both currently available HPV vaccines could theoretically prevent more than $70 \%$ of all $\alpha$-PV DNA-positive ESCC, although only if proved also to work against nongenital HPV-related cancers or their precursors.

\section{Future perspective}

- In order to provide conclusive evidence that HPV is a definitive causative factor in ESCC, we need more studies. A welldesigned large international case-control study with sufficient power indisputably to ascertain HPV rates in ESCC cases compared with controls without ESCC, using a uniform HPV testing methodology for all tissue samples, is the most practical way forward. 
America, Africa, Asia and Oceania were tested by a uniform HPV methodology and worldwide $\mathrm{HPV}$ type attribution in invasive cervical cancer was established [78]. In a perfect scenario, all tissue samples should be processed, for example, cut from paraffin blocks, and tested for HPV DNA in a single central laboratory with long experience in dealing with archival clinical specimens. ESCC tissue samples and tissue samples of normal esophageal mucosa should be collected from countries/areas covering the whole spectrum of ESCC incidence rates, from extremely low-incidence areas to areas with the highest incidence rates of ESCC, with minimal variations in specimen retrieval and storage. The study should not use tissue adjacent to the ESCC lesion (histologically normal esophageal tissue from resection specimens of ESCC) as 'controls', since there is a high potential for cross-contamination and spread of HPV from tumor tissue to adjacent nonmalignant esophageal tissue, creating false-positive results in the detection of HPV DNA in nontumor tissue. Finally, the case-control study should collect data on potential confounders and effect modifiers, and these should be adjusted for when examining the effect of HPV. These include at least age, gender, smoking, alcohol consumption, family history of esophageal cancer, pre-existing immunosuppression prior to cancer diagnosis, a history of thoracic irradiation, socio-economic status, diets high in red and processed meat, consumption of hot food and beverages, pickled foods, and diets low in fresh fruit and vegetables. In conclusion, any future case-control study to address the HPV-ESCC issue would need to be substantially larger and planned in a substantially different way than any of the currently published studies in order to provide conclusive evidence that HPV is a definitive causative factor in ESCC.

\section{Acknowledgements}

We are grateful to $M$ Sagadin for his help with literature search and data management.

\section{Financial \& competing interests disclosure}

The institution at which M Poljak, BJ Kocjan and L Hošnjak performed research on HPV epidemiology and pathogenesis, and have undertaken evaluations of various $H P V$ tests, has received research funding and/or free-ofcharge kits from Abbott and Merck and Co. Inc. M Poljak has also received travel grants and honoraria from Abbott, Roche, and Merck and Co. Inc. in the last 3 years for speaking and participation at scientific conferences and/or sitting on advisory boards. The authors have no other relevant affiliations or financial involvement with any organization or entity with a financial interest in or financial conflict with the subject matter or materials discussed in the manuscript, apart from those disclosed. This includes employment, stock ownership or options, expert testimony, patents received or pending, or royalties.

No writing assistance was utilized in the production of this manuscript.

\section{Open Access}

This work is licensed under the Creative Commons Attribution-NonCommercial 3.0 Unported License. To view a copy of this license, visit http://creativecommons.org/ licenses/by-nc-nd/3.0/

\section{References}

Papers of special note have been highlighted as:

- of interest

-• of considerable interest

1 de Villiers EM. Cross-roads in the classification of papillomaviruses. Virology 445, 2-10 (2013).

2 de Villiers EM, Fauquet C, Broker TR, Bernard HU, zur Hausen H. Classification of papillomaviruses. Virology 324(1), 17-27 (2004).

3 Doorbar J, Quint W, Banks L et al. The biology and life-cycle of human papillomaviruses. Vaccine 20 (Suppl. 5), F55-F70 (2012).

4 Bottalico D, Chen Z, Kocjan BJ, Seme K, Poljak M, Burk RD. Characterization of human papillomavirus type 120: a novel betapapillomavirus with tropism for multiple anatomical niches. J. Gen. Virol. 93(8), 1774-1779 (2012).

5 Bouvard V, Baan R, Straif K et al. A review of human carcinogens - Part B: biological agents. Lancet Oncol. 10 (4), 321-322 (2009).

6 Forman D, de Martel C, Lacey CJ et al. Global burden of human papillomavirus and related diseases. Vaccine 30 (Suppl. 5), F12-F23 (2012).

7 Fujs Komloš K, Kocjan BJ, Košorok P et al. Tumor-specific and gender-specific pre-vaccination distribution of human papillomavirus types 6 and 11 in anogenital warts and laryngeal papillomas: a study on 574 tissue specimens. J. Med. Virol. 84(8), 1233-1241 (2012).

8 Bernard HU. The clinical importance of the nomenclature, evolution and taxonomy of human papillomaviruses. J. Clin. Virol. 32(Suppl. 1), S1-S6 (2005).

9 Feltkamp MC, de Koning MN, Bavinck JN, Ter Schegget J. Betapapillomaviruses: innocent bystanders or causes of skin cancer. J. Clin. Virol. 43(4), 353-360 (2008).

10 Ferlay J, Shin HR, Bray F, Forman D, Mathers C, Parkin DM. GLOBOCAN 2008 v2.0, Cancer Incidence and Mortality Worldwide: IARC CancerBase No. 10 [Internet]. Lyon, France: International Agency for Research on Cancer; 2010. http://globocan.iarc.fr (Accessed 5 August 2013)

11 Ferlay J, Shin HR, Bray F, Forman D, Mathers C, Parkin DM. Estimates of worldwide burden of cancer in 2008: GLOBOCAN 2008. Int. J. Cancer 127, 2893-2917 (2010). 
12 Ferlay J, Bray F, Pisani P, Parkin DM. GLOBOCAN 2002. Cancer incidence, mortality and prevalence worldwide IARC CancerBase No. 5 [Internet]. Version 2.0. IARC Press, France (2004).

13 Syrjänen K. Esophageal squamous cell carcinoma: epidemiology and risk factors. In: Human Papillomavirus (HPV) Involvement in Esophageal Carcinogenesis. Nova Science Publishers Inc., NY, USA, 29-38(2010).

-. Excellent detailed review of the HPV involvement in esophageal carcinogenesis.

14 Liyanage SS, Rahman B, Ridda I et al. The aetiological role of human papillomavirus in oesophageal squamous cell carcinoma: a meta-analysis. PLoS ONE 8(7), e69238 (2013).

-. Landmark meta-analysis of 21 case-control studies, which provides the strongest evidence to date of an HPV-ESCC association.

15 Moradi A, de Villiers E, Mokhtari-Azad T et al. Detection of human papillomavirus DNA by PCR in esophageal squamous cell carcinoma from Turkmen Sahra, north-east of Iran. Iran. Biomed. J. 6(1), 19-23 (2002).

16 Pennathur A, Gibson MK, Jobe BA, Luketich JD. Oesophageal carcinoma. Lancet 381(9864), 400-412 (2013).

17 Secretan B, Straif K, Baan R et al. A review of human carcinogens - Part E: tobacco, areca nut, alcohol, coal smoke, and salted fish. Lancet Oncol. 10(11), 1033-1034 (2009).

- Important study, identifying group 1 human carcinogens linked with esophageal carcinoma.

18 Castellsague X, Munoz N, de Stefani E et al. Independent and joint effects of tobacco smoking and alcohol drinking of the risk of esophageal cancer in men and women. Int. J. Cancer 82(5), 657-664 (1999).

19 Islami F, Boffetta P, Ren J-S, Pedoeim L, Khatib D, Kamangar F. High-temperature beverages and foods and esophageal cancer risk - a systematic review. Int. J. Cancer 125(3), 491-524 (2009).

20 Syrjänen K. Geographic origin is a significant determinant of human papillomavirus prevalence in oesophageal squamous cell carcinoma: Systematic review and meta-analysis. Scand. J. Infect. Dis. 45(1), 1-18 (2012).

- Largest systematic review and first formal meta-analysis of studies reporting on HPV prevalence in ESCC that showed the presence of HPV in almost one third of ESCC with substantial geographic differences.

21 Syrjänen KJ. Histological changes identical to those of condylomatous lesions found in esophageal squamous cell carcinomas. Arch. Geschwulstforsch 52(4), 283-292 (1982).

-. Pioneer study; first scientific report suggesting an etiological role of HPV in the development of neoplasms of the esophagus.

22 Syrjänen K. HPV and oesophageal carcinoma. In: Papillomavirus Research: From Natural History to Vaccines and Beyond. Campo MS (Ed.). Caister Academic Press, UK, 229-253(2006).

23 Liyanage SS, Segelov E, Garland SM et al. Role of human papillomaviruses in esophageal squamous cell carcinoma. Asia Pac. J. Clin. Oncol. 9(1), 12-28 (2013).

24 Poljak M, Cerar A, Seme K. Human papillomavirus infection in esophageal carcinomas: a study of 121 lesions using multiple broad spectrum polymerase chain reaction and literature review. Hum. Pathol. 29(3), 266-271 (1998).

25 Syrjänen K. HPV infections and oesophageal cancer. J. Clin. Pathol. 55(10), 721-728 (2002).

26 Lenhart D, Rifley W, Manalo P, McGregor B. Association of human papillomavirus with esophageal neoplasms. Dis. Esophagus 4, 123-128 (1991).

27 Li T, Lu Z-M, Chen K-N et al. Human papillomavirus type 16 is an important infectious factor in the high incidence of esophageal cancer in Anyang area of China. Carcinogenesis 22(6), 929-934 (2001).

28 Kiki I, Gundogdu M, Polat F, Gundogdu C. Detection of human papillomavirus infection in esophageal carcinomas by the histopathological method and polymerase chain reaction technique. Turk. J. Med. Sci. 32(3), 223-230 (2002).

29 Li S, Li Y, Wang LD et al. Detection of human papillomavirus in tissues of esophageal carcinomas by polymerase chain reaction. Chin. J. Exp. Clin. Virol. 22(4), 251-253 (2008).

30 Mohseni MSM. Detection of human papilloma virus in esophageal squamous cell carcinoma in Guilan province. J. Clin. Diagnost. Res. 4, 2373-2377 (2010).

31 Emadian O, Naghshvar F, Rafiei A, Maleki L, Torabizadeh Z, Rezaei Far M. Correlation of human papillomavirus infection with esophageal squamous cell carcinoma. J. Babol. Univ. Med. Sci. 13(4), 54-59 (2011).
32 Mancilia L, Carrascal E, Tamayo O et al. Role of human papillomavirus type 16 in squamous cell carcinoma of upper aerodigestive tracts in Colombian patients. Int. J. Cancer Res. 7, 222-232 (2011).

33 Guo F, Liu Y, Wang X et al. Human papillomavirus infection and esophageal squamous cell carcinoma: a case-control study. Cancer Epidemiol. Biomarkers Prev. 21(5), 780-785 (2012).

34 Vaiphei K, Kochhar R, Bhardawaj S, Dutta U, Singh K. High prevalence of human papillomavirus in esophageal squamous cell carcinoma: a study in paired samples. Dis. Esophagus 26(3), 282-287 (2013).

35 Yahyapour Y, Shamsi-Shahrabadi M, Mahmoudi M et al. Evaluation of human papilloma virus infection in patients with esophageal squamous cell carcinoma from the Caspian Sea area, north of Iran. Asian Pac. J. Cancer Prev. 13(4), 1261-1266 (2012).

36 Noori S, Monabati A, Ghaderi A. The prevalence of human papilloma virus in esophageal squamous cell carcinoma. Iran J. Med. Sci. 37(2), 126-133 (2012).

37 Löfdahl HE, Du J, Näsman A et al. Prevalence of human papillomavirus (HPV) in oesophageal squamous cell carcinoma in relation to anatomical site of the tumour. PLoS ONE 7(10), e46538 (2012).

38 Dąbrowski A, Kwaśniewski W, Skoczylas T, Bednarek W, Kuźma D, Goździcka-Józefiak A. Incidence of human papilloma virus in esophageal squamous cell carcinoma in patients from the Lublin region. World J. Gastroenterol. 18(40), 5739-5744 (2012).

$39 \mathrm{Hu}$ JM, Li L, Chen YZ et al. Human papillomavirus type 16 infection may be involved in esophageal squamous cell carcinoma carcinogenesis in Chinese Kazakh patients. Dis. Esophagus doi:10.1111/ dote.12009(2012) (Epub ahead of print).

40 Wang YF, Wang XS, Gao SG et al. Clinical significance of combined detection of human papilloma virus infection and human telomerase RNA component gene amplification in patients with squamous cell carcinoma of the esophagus in northern China. Eur. J. Med. Res. 18, 11 (2013).

41 de Oliveira Mota MT, Bonilha JL, Rosa BM et al. High-risk human papillomaviruses in two different primary tumors in the same patient. Int. J. Urol. doi:10.1111/iju.12096 (2013) (Epub ahead of print).

42 Schäfer G, Kabanda S, van Rooyen B, Maruši MB, Banks L, Parker MI. The role of inflammation in HPV infection of the Oesophagus. BMC Cancer 13, 185 (2013). 
43 Sahasrabuddhe VV, Castle PE, Follansbee S et al. Human papillomavirus genotype attribution and estimation of preventable fraction of anal intraepithelial neoplasia cases among HIV-infected men who have sex with men. J. Infect. Dis. 207(3), 392-401 (2013).

44 Lu XM, Monnier-Benoit S, Mo LZ, Xu SY, Pretet JL, Lium Z. Human papillomavirus in esophageal squamous cell carcinoma of the high-risk Kazakh ethnic group in Xinjiang, China. Eur. J. Surg. Oncol. 34(7), 765-770 (2008),

45 Koh JS, Lee SS, Baek HJ, Kim YI. No association of high-risk human papillomavirus with esophageal squamous cell carcinomas among Koreans, as determined by polymerase chain reaction. Dis. Esophagus 21(2), 114-117 (2008).

46 Yang W, Zhang Y, Tian X, Ning T, Ke Y. p53 Codon 72 polymorphism and the risk of esophageal squamous cell carcinoma. Mol. Carcinog. 47(2), 100-104 (2008).

47 Bognar G, Imdahl A, Ledniczky G, Ondrejka P. Possible role of human papilloma virus infection in response to neoadjuvant therapy in patients with esophageal cancer. Hepatogastroenterology 55(81), 93-97 (2008).

48 Tornesello ML, Monaco R, Nappi O, Buonauguro L, Buonauguro FM. Detection of mucosal and cutaneous human papillomaviruses in oesophagitis, squamous cell carcinoma and adenocarcinoma of the oesophagus. J. Clin. Virol. 45(1), 28-33 (2009).

49 Zhao XY, Li SY, Li Y et al. Detection of human papillomavirus in esophageal carcinoma tissues from Baoding City of Hebei Province. Zhonghua Shi Yan He Lin Chuang Bing Du Xue Za Zhi 23(2), 91-93 (2009).

50 Hussain S, Bharti AC, Salam I et al. Transcription factor AP-1 in esophageal squamous cell carcinoma: alterations in activity and expression during human papillomavirus infection. BMC Cancer 9 , 329-334 (2009).

51 Herrera-Goepfert R, Lizano M, Akiba S, Carrillo-Garcia A, Becker-D’Acosta M. Human papilloma virus and esophageal carcinoma in a Latin-American region. World J. Gastroenterol. 15(25), 3142-3147 (2009).

52 Erol D, Bulut Y, Yuce H, Ozercan IH. Investigation of the presence of human papillomavirus DNA in various gastrointestinal carcinoma samples. Mikrobiyol. Bul. 43(2), 259-268 (2009).

53 Bellizzi AM, Woodford RL, Moskaluk CA, Jones DR, Kozower BD, Stelow EB. Basaloid squamous cell carcinoma of the esophagus: assessment for high-risk human papillomavirus and related molecular markers. Am. J. Surg. Pathol. 33(11), 1608-1614 (2009).

54 Zhang D, Zhang Q, Zhou L et al. Comparison of prevalence, viral load, physical status and expression of human papillomavirus-16, -18 and -58 in esophageal and cervical cancer: a case-control study. BMC Cancer 10, 650 (2010).

55 Wang X, Tian X, Liu F et al. Detection of HPV DNA in esophageal cancer specimens from different regions and ethnic groups: a descriptive study. BMC Cancer 10, 19 (2010).

56 Tonna J, Palefsky JM, Rabban J, Campos GM, Theodore P, Ladabaum U. Esophageal verrucous carcinoma arising from hyperkeratotic plaques associated with human papilloma virus type 51. Dis. Esophagus 23(5), e17-e20 (2010).

57 Liu WK, Jiang XY, Zhang MP, Zhang ZX. The relationship between HPV16 and expression of cyclooxygenase-2, p53 and their prognostic roles in esophageal squamous cell carcinoma. Eur. J. Gastroenterol. Hepatol. 22(1), 67-74 (2010).

58 Koshiol J, Wei WQ, Kreimer AR et al. No role for human papillomavirus in esophageal squamous cell carcinoma in China. Int. J. Cancer 127(1), 93-100 (2010).

59 Ding GC, Ren JL, Chang FB et al. Human papillomavirus DNA and P16(INK4A) expression in concurrent esophageal and gastric cardia cancers. World J. Gastroenterol. 16(46), 5901-5906 (2010).

60 Antonsson A, Nancarrow DJ, Brown IS et al. High-risk human papillomavirus in esophageal squamous cell carcinoma. Cancer Epidemiol. Biomarkers Prev. 19(8), 2080-2087 (2010).

61 Malik SM, Nevin DT, Cohen S, Hunt JL, Palazzo JP. Assessment of immunohistochemistry for p16INK4 and high-risk HPV DNA by in situ hybridization in esophageal squamous cell carcinoma. Int. J. Surg. Pathol. 19(1), 31-34 (2011).

62 Zhang QY, Zhang DH, Shen ZY, Xu LY, Li $\mathrm{EM}, \mathrm{Au}$ WW. Infection and integration of human papillomavirus in esophageal carcinoma. Int. J. Hyg. Environ. Health 214(2), 156-161 (2011).

63 Wang WC, Wu TT, Chandan VS, Lohse CM, Zhang L. Ki-67 and ProExC are useful immunohistochemical markers in esophageal squamous intraepithelial neoplasia. Hum. Pathol. 42(10), 1430-1437 (2011).
64 Hussain S, Singh N, Salam I et al. Methylation-mediated gene silencing of suppressor of cytokine signaling-1 (SOCS-1) gene in esophageal squamous cell carcinoma patients of Kashmir valley. J. Recept. Signal Transduct. Res. 31(2), 147-156 (2011).

65 Goto A, Li CP, Ota $\mathrm{S}$ et al. Human papillomavirus infection in lung and esophageal cancers: analysis of 485 Asian cases. J. Med. Virol. 83(8), 1383-1390 (2011).

66 Cui MC, Li Y, He X, Wang XL, Wang LD, Liu HT. Study of human papillomavirus in biopsy tissue specimens of esophageal carcinomas in Linzhou city. Zhonghua Shi Yan He Lin Chuang Bing Du Xue Za Zhi 25(1), 39-41 (2011).

67 Castillo A, Koriyama C, Higashi M et al. Human papillomavirus in upper digestive tract tumors from three countries. World J. Gastroenterol. 17(48), 5295-5304 (2011).

68 Landau M, Goldblum JR, Deroche T et al. Esophageal carcinoma cuniculatum: report of 9 cases. Am. J. Surg. Pathol. 36(1), 8-17 (2012).

69 Doxtader EE, Katzenstein AL. The relationship between p16 expression and high-risk human papillomavirus infection in squamous cell carcinomas from sites other than uterine cervix: a study of 137 cases. Hum. Pathol. 43(3), 327-332 (2012).

70 Abdirad A, Eram N, Behzadi AH et al. Human papillomavirus detected in esophageal squamous cell carcinoma in Iran. Eur. J. Intern. Med. 23(2), 59-62 (2012).

71 Gupta N, Barwad A, Rajwanshi A, Kochhar R. Prevalence of human papillomavirus in esophageal carcinomas: a polymerase chain reaction-based study. Acta Cytol. 56(1), 80-84 (2012).

72 Potočnik M, Kocjan BJ, Seme K, Luzar B, Babič DZ, Poljak M. Beta-papillomaviruses in anogenital hairs plucked from healthy individuals. J. Med. Virol. 78(12), 1673-1678 (2006).

73 de Villiers EM, Gunst K. Characterization of seven novel human papillomavirus types isolated from cutaneous tissue, but also present in mucosal lesions. J. Gen. Virol. 90(8), 1999-2004 (2009).

74 Bottalico D, Chen Z, Dunne A et al. The oral cavity contains abundant known and novel human papillomaviruses from the Betapapillomavirus and Gammapapillomavirus genera. J. Infect. Dis. 204(5), 787-792 (2011).

75 Forslund O, Johansson H, Madsen KG, Kofoed K. The nasal mucosa contains a large 
REVIEW

spectrum of human papillomavirus types

from the Betapapillomavirus and

Gammapapillomavirus genera. J. Infect. Dis. 208(8), 1335-1341 (2013).

76 Cao B, Tian X, Li Y et al. LMP7/TAP2 gene polymorphisms and HPV infection in

esophageal carcinoma patients from a high incidence area in China. Carcinogenesis 26(7), 1280-1284 (2005).

77 Poljak M. Prophylactic human papillomavirus (HPV) vaccination and primary prevention of cervical cancer: issues and challenges. Clin. Microbiol. Infect. 18(Suppl. 5), 64-69 (2012).

78 de Sanjose S, Quint WG, Alemany L et al. Human papillomavirus genotype attribution in invasive cervical cancer: a retrospective cross-sectional worldwide study. Lancet Oncol. 11(11), 1048-1056 (2010).

79 Toh Y, Kuwano H, Tanaka S. Detection of human papillomavirus DNA in esophageal carcinoma in Japan by polymerase chain reaction. Cancer 70 (9), 2234-2238 (1992). 